JPE (Jurnal Pendidikan Edutama) Vol. 5 No. 1 Januari 2018

P-ISSN : 2339-2258 (Print) E-ISSN: 2548-821X (Online)

http://ejurnal.ikippgribojonegoro.ac.id/index.php/JPE

\title{
LEARNER AUTONOMY ON ESSAY WRITING ACCURACY
}

\author{
Moh. Hafidz \\ Prodi Pendidikan Bahasa Inggris, STKIP PGRI Bangkalan \\ email:mohhafidz@stkippgri-bkl.ac.id
}

\begin{abstract}
Learner autonomy on writing is independently teaching and learnin that keeps students' control to explore their knowledge and experiences in written language, find out and avaluate their errors based on the conceptual courses to make accurately simple essay. The aim was to know the effectiveess of the learner autonomy on writing accuracy. This quatitative research conducted in one group pretest and postes design. The number of sample was 21 students in Bangkalan. The instrument were tests to gain students' writing score before and after treatment. Researcher statistically analyzed the data using SPSS 23 version by running a Paired Samples Test. The result shown the means of pretes score was 66,83 and posttes score was 74,57, Paired Samples Correlations was 0,614 (strong correlation). Significance was 0,005, it means that $\alpha(0,05)$ is higher than $\rho$ value $(0,005)$ with high variance of mean value (14,091). As a result, the hypothesis (H1) was recepted that learner autonomy contributed effectively to learners' in organizing own ideas (Ene, 2006) such as making a topic map becomes some explanable sub-topics, writing down main and supporting idea, clustering some objects, editing next and learners absolutey accumulate some selected vocabularies in appropriate topics (Chengping W, 2008).
\end{abstract}

Keyword: Learner Autonomy, Learning process, outcomes

\begin{abstract}
Absrak: Pembelajaran otonomi adalah pembelajaran mandiri yang mengontrol mahasiswa untuk menyampaikan gagasan dan pengalamannya, mencatat dan mengevaluasi kesalahan yang terjadi dalam penulisan esai sederhana berdasarkan pembelajaran yang tersetruktur. Tujuaa adala untuk mengetahui efektifitas pembelajaran otonomi terhadap akurasi tulisan secara statistic. Penelitian ini dilakukan dengan menggunakan desain tes awal dan akhir. Jumlah sampel terdiri dari 21 siswa di Bangkalan. Isntrumen yang digunakan adalah tes untuk mengetahui hasil nilai mahasiswa sebelum dan sesudah melakukan pembelajaran otonomi. Peneliti menganalisa data dengan menggunakan versi SPSS 23 dengan menggunakan sampel tes yang berpasangan. Hasil rata-rata tes awal adalah 66,83 dan tes akhir adalah 74,57, dengan corelasi sampel berpasangannya adalah 0,614 (kuat). Sedangkan signifikansinya adalah 0,005 , artinya $\alpha(0,05)$ lebih besar daripada $\rho$ value $(0,005)$ dengan varian nilai ratarata yang tinggi (14,091). Hasil hipotesis (H1)-nya diterima bahwa pembelajara otonomi berkontribusi secara efektif terhadap pengorganisasian gagasan mahasiswa sendiri (Ene, 2006) seperti memetakan suatu topik menjadi sub-topik yang mudah dijelaskan, pengelompokan objek tertentu untuk dijadikan topik, kemudian mengeditnya dan tentunya dapat memilih kosakat-kosakata yang sesuai dengan topiknya (Chengping W, 2008).
\end{abstract}

Kata kunci: Pembelajaran otonomi, proses pembelajaran, hasil

\section{INTRODUCTION}

Writing is behavioral process to deliver some written messages in mechanical products (Langan, 2010). Writing as skill absolutely requires habitual acts to force a writing competence through student's leraning activities. The basics cocepts on writing are type, purpose and length. The first, type is ditermining the writing format such as letter, notes, report, project, essay, thesis or disertation and article or paper. The second, purpose is an aim of the final products, those are formal or informal information. The last, lenght is number of words which suits with type's necessity (Bailey, 2003). Maesuring this 
concept (Hogue, 2007) assesses essay writing aspects through format, punctuaition and mechanics, content, organization, grammar and sentence structure.

Furthermore, this basic writing concept conducted in leaning autonomy when the students are conciousely believe that their skill, knowledge, experience and environment support to develop writing skill (Vazquez, 2015). This statement stresses on the student's control and responsibily which learning adjusts the student's writing competence. On his journal, Illes (2015) argues:

"when developing LA, the emphasis should shift from aspects related to the learning process (e.g. setting learning objectives, monitoring learning, evaluating learning outcomes, etc.) to communicative processes since the teacher's main concern should be to develop learners' autonomy as language users"

It means that students are able to transfer the own kognitive aspect and formulate the own surrounding facts in written message (William, 2003), the students understand the material, target and appropriate strategy while learning process. Moreover, students due to the competence based and get more responsibilities to enhance their result tasks in the own rules and determine some choices which need evaluation or the final written product (Ahmadzadeh, 2014).

In language teaching process (AlBusaidi, 2012), professional language learner autonomy fulfills some characterics such autonomy is a construct of capacity, autonomy involves a willingness on the part of the learner to take responsibility for their own learning, the capacity and willingness of learners to take such responsibility is not necessarily innate, complete autonomy is an idealistic goal, there are degrees of autonomy, the degrees of autonomy are unstable and variable, autonomy is not simply a matter of placing learners in situations where they have to be independent, developing autonomy requires conscious, awareness of the learning process - i.e. conscious reflection and decision-making, promoting autonomy is not simply a matter of teaching strategies, autonomy can take place both inside and outside the classroom, autonomy has a social as well as an individual dimension, the promotion of autonomy has a political as well as psychological dimension, autonomy is interpreted differently by different cultures.

Learning aoutonomy does not as simply as teacher center learning which the teacher is more dominant in learning, the students take appluse to the teacher's activities and understimate their skill, knowledge, experiences eventhough neglect the power of environment, learner autonomy conceptualized in students' classroom situation which disting to other ones, are: students manage in their own class, students do based on their skill, students' innate ability is supported by classroom instruction, students are evaluated for their process, student's chose their learning porpuses (David Nunan, 2003).

So, all of student's ctivities are dependent and the learning outcomes are out of learning set because the students can not explore their ability and imatate the innovative ones out of the classroom. Studetns' background knowledges determine the own process of learnig specially on te results of writing skill products.

Motivating structurally the autonomous student's ideas and creativities conducts a suite approach such as workshop 
which focuses on discovery based approach, this approach drills students' skill more active than teacher learning center, because the teacher encourage students to due some activities that related with learner autonomy concept o writing. Ray (2001) states:

"Basically, a writing workshop consists of three components: (1) a 15-minute mini lesson; (2) approximately 20 minutes of independent student writing; and (3) 10 minutes of some form of sharing to wrap up the workshop. ......"

In early meeting of writing class, some learners were scary when the researcher was asking them to write in free writing at home. The next, All of students fulfilled the tasks in vary formats, content, and orgnanization. The students who submitted the product (free writing) are absolutely the writer because they are able to describe the fact in written text, moreover they are not a novelist or journalist (William, 2003). Learners writing skill appears when researcher asked them to mention their writing products such as diary, short story and writing portofolios.

Researcher intended to due an effective learning through learner autonomy. Learner autonomy is conceptualized independently teaching and learnin that keeps students' control to actualize their own knowledge and experiences, take notes and avaluate their own faults themselves (Ene, 2006). Learner autonomy makes students are more active than teacher. Moreover, the teacher acquires some rules to conduct teaching and learning in and out of the class which bases on students activities. The teacher is not fasilitator only, but also manager. Students process of actualizing their idea into written format absolutely have own technique which empowers their knowledge and experiences while they are writing some topics.

In contrast, Learner autonomy that investigated in West Anhui University found some unpleased results such as the lack of students vocabularies, unappropriate subject and different understanding between teacher and students (Chengping $\mathrm{W}$, 2008). This indicates that learner autonomy is not as simple as dependent learning which most of teachers assume that student's knowledge is on the teacher's authorized which all of student's written products are their responsibility to be evaluated and corrected (Kulsirisawad, 2012) then, published to the students in order to find out their written faults.

\section{METHODOLOGY}

A total participants of this research were 30 students in Bangkalan. The participants were from different graduation background such as senior high school was $34 \%$, vocational school $33 \%$ and islamic senior high school $33 \%$. The everage of participants english score was 7,0 and took English language teachers. Paired Samples test was used in this research. Instrument of this research is test (Darmadi, 2014) to investigate the learner autonomy of the subjects, the tes was designed which consits of format (5 points), punctuaition and mechanics (5 points), content (20 points), organization (35 points), grammar and sentence structure (35 points) (Alice Oshima, 2007).

The data are gained from prepared test (pre-test) to know the participants writing skill by one group pretest posttest design (Creswell, 2009). The purpose of this study is to identify learner autonomy contribute to the students' essay writing accuracy. Further, learning autonomy applied in workshop approach which students got 10 treatments and 4 exercises, 
those devided in two assessments were individual and peer assessments. Own assessments conducted after training then made an essay and evaluated by theirselves, peer assessments due to make an essay than, evaluated by their patner end gaving back after corrrecting.

To get information of student's achievement, reseacher tested participants (post-tes) to make an essay and submitted it to know the learner autonomy effects on essay writing aspects, researcher used a statistical technique was used to identify whether the mean and standards error of mean and standard deviation of the test. The test was standardised by Oshimas' creterias which used in English language learning.

\section{DISCUSSION}

The data currently were obtained from a pretest and posttest. Pretest early conducted to measure the learner's writing ability before threatment class. In the class, learner's autonomy applied to threat the learner as long as learning process including learner's activities, individual or group work tasks and final test. Posttest was gained from final test to measure the the learner's autonomy contributed statistically on learners' essay writing accuracy. The result of

Pretest and posttest designed and calculated based on Oshimas scoring rubrics. Statiscal analyzed data was SPSS 23 version by running a Paired Samples Test. The result of this analyze to answer the tentatively hypothesis that learners' authonomy contributes signifcantly on learners' essay writing accuracy. In addition, if the learners have higher score after the treatment class, the hypothesis (H1) is recepted and $\mathrm{HO}$ is rejected in contrast.

\section{Testing the hypothesis}

The hypothesis was tested in Paired Samples Test to analyze the result of pretest and postest statistically after computing both scores (table.3).

Table 1. Describing the Statisticcally Paired Samples of Learner Autonomy Contribute to the Students' Essay Writing Accuracy

\begin{tabular}{|c|c|c|c|c|}
\hline \multicolumn{4}{|c|}{ Paired Samples Statistics } \\
\hline & Mean & $\mathrm{N}$ & $\begin{array}{c}\text { Std. } \\
\text { Deviatio } \\
\mathrm{n}\end{array}$ & $\begin{array}{c}\text { Std. } \\
\text { Error } \\
\text { Mean }\end{array}$ \\
\hline $\begin{array}{c}\text { Pai } \\
\text { Pr } 1\end{array} \quad \begin{array}{c}\text { Prete } \\
\text { st } \\
\text { Poste }\end{array}$ & 66,83 & 30 & 17,835 & 3,256 \\
\hline
\end{tabular}

Paired Samples Statistics indicates the mean of pretes score is 66,83 and posttes score is 74,57 . So, posttest score is higher than posttest. 
Table 2 Describing the Paired Samples Correlations of Learner Autonomy Contribute to the Students' Essay Writing Accuracy.

\begin{tabular}{|} 
Paired Samples Correlations \\
\begin{tabular}{|cc|c|c|c|}
\hline & & $\mathrm{N}$ & $\begin{array}{c}\text { Correlati } \\
\text { on }\end{array}$ & Sig. \\
\hline $\begin{array}{c}\text { Pair } \\
1\end{array}$ & $\begin{array}{c}\text { Pretest \& } \\
\text { Postest }\end{array}$ & 30 &, 614 &, 000 \\
\hline
\end{tabular}
\end{tabular}

Paired Samples Correlations shows that both pretest and posttes has stongly correlation after applying Learner
Autonomy in treatmen class. The table 2 points out 0,614 .

Table 3 Describing the Paired Samples Test of Learner Autonomy Contribute to the Students' Essay Writing Accuracy.

Paired Samples Test

\begin{tabular}{|c|c|c|c|c|c|c|c|c|}
\hline & \multicolumn{5}{|c|}{ Paired Differences } & \multirow[t]{2}{*}{$\mathrm{T}$} & \multirow[t]{2}{*}{$\mathrm{df}$} & \multirow{3}{*}{$\begin{array}{l}\text { Sig. (2- } \\
\text { tailed) }\end{array}$} \\
\hline & \multirow[t]{2}{*}{ Mean } & \multirow[t]{2}{*}{$\begin{array}{c}\text { Std. } \\
\text { Deviation }\end{array}$} & \multirow[t]{2}{*}{$\begin{array}{c}\text { Std. Error } \\
\text { Mean }\end{array}$} & \multicolumn{2}{|c|}{$\begin{array}{l}\text { 95\% Confidence } \\
\text { Interval of the } \\
\text { Difference }\end{array}$} & & & \\
\hline & & & & Lower & Upper & & & \\
\hline $\begin{array}{cc}\text { Pair 1 } & \text { Pret } \\
& \text { est }- \\
& \text { Post } \\
& \text { est }\end{array}$ & $-7,733$ & 14,091 & 2,573 & $-12,995$ & $-2,472$ & $-3,006$ & 29 & ,005 \\
\hline
\end{tabular}

Paired Samples Test is statistically design to analyze the pretest and postest result after threatmen class. The table 3 in Sig. (2-tailed) column shows 0,005, it means that learner autonomy contributes signficantly to the students' essay writing accuracy. In other words, $\alpha(0,05)$ is higher than $\rho$ value $(0,005)$ with high variance of mean value which pointed it out in standard deviation coloumn is 14,091. As a result, the hypothesis (H1) is recepted.

Learner autonomy is learner-centred approach to language teaching (David Nunan, 2003) contribute effectively to learners' in organizing alternatively own ideas (Ene, 2006) because the learners are able to make a topic map becomes some explanable sub-topics and chose the selected ones which support to the structurally paragraphs becomes simple essay which completely arranged in outline format (Langan, 2010).

The content of essay, the learners trained to discuss, analyze, write and edit (in peer) the interesting topics (Ray, 2001), the learners have unique and various knowledge and experience to explore their ideas in written language because of their variety writing technique such as writing down main idea and supporting idea of the essay title, clustering some objects based on the title and directly writing an essay by editing next.

Training class conducted to manage the situation (David Nunan, 2003) that learners are formal writers (Bailey, 2003), (William, 2003) who communicate in written language (Illes, 2015) especially in essay type. This type requires accurately information to make readers easily 
understand. Moreover, learners absolutey accumulate some selected sufficient vocabularies in actual and appropriate topics (Chengping W, 2008). Students' vocabularies are more daily words that utilized in sentences and pragraph.

\section{CONCLUSION}

Learner autonomy contributes effectively on essay writing accuracy by providing the means of pretes score was 66,83 and posttes score was 74,57 , Paired Samples Correlations was 0,614 (strong correlation). Significance was 0,005 , it means that $\alpha(0,05)$ is higher than $\rho$ value $(0,005)$ with high variance of mean value $(14,091)$. As a result, the hypothesis (H1)

\section{BIBLIOGRAPHY}

Ahmadzadeh, R. (2014). Learner Autonomy in Practice. International Journal on New Trends in Education and Their Implications , 54-55.

Al-Busaidi, S. B. (2012). Learner Autonomy: English Language Teachers' Beliefs and Practices. UK: British Council.

Alice Oshima, A. H. (2007). Introduction to Academic Writing. United Stated of America: Longman.

Bailey, S. (2003). Academic Writing A Practical Guide for Students. New York: Routledge Falmer Taylor \& Francis Group.

Chengping W, R. H. (2008). Net-Based Learner Autonomy, Its Problems and Possible Solutions-A Case Study in WAHU, China. English Language Teaching , 108-110. was recepted that learner autonomy contributed effectively to learners' in organizing alternatively own ideas (Ene, 2006) such as make a topic map becomes some explanable sub-topics, writing down main and supporting idea, clustering some objects, editing next and learners absolutey accumulate some selected vocabularies in actual and appropriate topics (Chengping W, 2008).

Creswell, J. W. (2009). Qualitative, Quantitative, and Mixed Method Approach. California: Sage.

Darmadi, H. (2014). Metode Penelitian Pendidikan dan Sosial Teori dan Konsep. Bandung: Alfabeta.

David Nunan, J. C. (2003). English As A Second Or Foreign Language. London: Taylor \& Francis Ltd.

Ene, C. H. (2006). Grammatical Accuracy and Learner Autonomy in Advanced Writing. ELT Journal , 1.

Hogue, A. O. (2007). Introduction to Academic Writing. United States of America: Longman.

Kulsirisawad, P. (2012). Developing Learner Autonomy in EFL Writing Classrooms via Peer Feedback. CULI National Seminar (pp. 3-5). Bangkok: Chulalongkorn University Language Institute. 
Langan, J. (2010). Exploring Writing Sentences and Paragraphs. New York: Connect Learn Succed.

Vazquez, B. M. (2015). Learner Autonomy as a Defensible Educational Goal in Modern Language Education. Journal of
English and Spanish Studies, 101-102.

William, J. D. (2003). Preparing to Teach riting: Research, Theory and Practice. New Jersey: Lawrence Erlbaum Associates. 
16 JURNAL PENDIDIKAN EDUTAMA, Vol.5, No.1 Januari 2018 